\title{
スルフォンアミド及びスルフォン誘導體と尿素 との協同作用機序についての一考察
}

厚生省東京德生試驗所細菌部（部長・八田貞军博士指導）

宮 本 晴 夫

\section{1まえがき}

各種のスルフォンアミド及びスルフォン誘導體 と，尿素との協同作用の强さを Aerobacter aerogenes (327) について, 命成培地を用い比較檢討 してみオとこう，スルフォンアミド誘導體中 $\mathrm{N}^{4}$ の水素原于范フタール酸で置換されたもの， $N^{1} を$ 脂肪族基並びに異項環基で㯰換されたもの，及び スルフォン誘導䗒については，强弱の程度の差は あるが一楞に協同現象を認めたこが，スルフォンア ミド誘導體中 $\mathrm{N}^{4} の \mathrm{NH}_{2}$ 基告他の原子團で置き 換えられたものには，全く協同現象の成立しない といら興味ある專實を觀察した。

\section{1 實 驗 方 法}

まず合成培地 $\left(\left(\mathrm{NH}_{4}\right) \mathrm{H}_{2} \mathrm{PO}_{4} 1.5 \mathrm{~g} ， \mathrm{~K}_{2} \mathrm{HPO}_{4}\right.$ $1.0 \mathrm{~g}, \mathrm{MgSO}_{4} \cdot 7 \mathrm{H}_{2} \mathrm{O} 0.2 \mathrm{~g}$ ，クエンサンソーダ $2.5 \mathrm{~g}$ ，蒸滔水 1000 c.c. pH 7.2 7.4) で各檢體 の倍數稀釋液崖作り,これを2群に分けて一群に
は尿素を 100 倍稀釋となるように招え，他の一群 は尿素を加えないで對照とした．接種菌量は合成 培地に 3 代以上繼代培養した菌の $1,000 \sim 5,000$

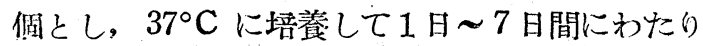
菌の發育狀況を溷濁度を指標として觀察七た。實 驗に供した檢體は次の 20 種である.（1）スル ファミン (2)アセトスルファミン (3) スルファ グアニデン (4) スルファチアゾール（5）スル ファメチールチアゾール（6）カルボキシールス ルファチアゾール（7）カルボキシールスルファ メチールチブゾール（8）スルファメチールチオ ダイアゾール（ルコシール）（9）スルファダイ アヂン (10) スルファメチールダイアヂン（スル ファメラヂン) (11) スルファメチールダイアヂ ン（スルファメサヂン）（12）フタリールスルフ アチアゾール) (13) フタリールアセトスルファミ ン(14) プロミゾール (15) メチルプロミゾール (16) ヒドロオキシルメチルプロミゾール (17) メ ルカプタンメチルプロミゾール (18) マルファニ

第 1 表 スルフアチアゾールと尿素との協同作用

\begin{tabular}{|c|c|c|c|c|c|c|c|c|c|c|c|}
\hline 制 & 定 & $\begin{array}{l}S . T . Q \\
\text { 稀釋倍數 }\end{array}$ & $10-5$ & $\frac{10^{-5}}{2}$ & $\frac{10^{-5}}{4}$ & $\frac{10^{-5}}{8}$ & $\frac{10^{-5}}{16}$ & $\frac{10^{-5}}{32}$ & $\frac{10^{-5}}{64}$ & $\frac{10^{-5}}{128}$ & $\frac{S . T .+ \text { 尿素 }}{S . T .}$ \\
\hline \multirow{2}{*}{1} & \multirow{2}{*}{ 日 } & 尿素加 & - & - & - & - & - & - & - & - & \multirow{2}{*}{8} \\
\hline & & 對 照 & - & - & - & 一 & - & + & \# & H & \\
\hline \multirow{2}{*}{3} & \multirow{2}{*}{ 日 } & 尿素加 & - & - & - & $\dot{-}$ & - & - & \pm & + & \multirow{2}{*}{4} \\
\hline & & 對 照 & - & - & - & - & + & $H$ & 卅 & Hf & \\
\hline \multirow{2}{*}{5} & \multirow{2}{*}{ 日 } & 尿素加 & - & - & - & - & + & + & \# & $\#$ & \multirow{2}{*}{4} \\
\hline & & 對 照 & - & - & H & H & 卅 & 卅 & \# & H & \\
\hline \multirow{2}{*}{7} & \multirow{2}{*}{ 日 } & 尿素加 & - & - & - & - & \# & 井 & \# & Hf & \multirow{2}{*}{4} \\
\hline & & 對 照 & - & - & H & 册 & \# & 卅 & \# & H & \\
\hline
\end{tabular}

註Ｓ. T. はスルフアチアゾールの略一〜菌の發育を認めないもの 土,, , H, H〜菌の發育程度を示す. 
第 2 表 スルフォンアミド文びスルフォン誘導澧と尿素との協同效果

\begin{tabular}{|c|c|c|c|c|c|c|c|c|c|}
\hline 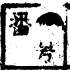 & 体体定日数 & 1 & 2 & 3 & 4 & 5 & 6 & 7日 & 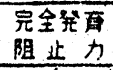 \\
\hline (1) & $\mathrm{NH}_{2} \bigcirc \mathrm{sO}_{2} \mathrm{NH}_{2}$ & $>8$ & 8 & 8 & 4 & 4 & 4 & 4 & $501 \mathrm{mg} \%$ \\
\hline (2) & $\mathrm{NH}_{2} \circlearrowright \mathrm{SO}_{2} \mathrm{NH}$ & $>2$ & 4 & 8 & 2 & 2 & 2 & 2 & 12.5 \\
\hline (3) & $\mathrm{NH}_{2} \bigcirc \mathrm{SO}_{2} \mathrm{~N}$ & 16 & 16 & 4 & 4 & 4 & 4 & 4 & 25 \\
\hline (4) & $\mathrm{NH}_{2} \bigcirc \mathrm{SO}_{2} \mathrm{~N}$ & $>8$ & $>8$ & 4 & 4 & 4 & 4 & 4 & 0.5 \\
\hline$(5)$ & $\mathrm{NH}_{2} \longrightarrow \mathrm{SO}_{2} \mathrm{NH}^{1}$ & $>4$ & 4 & 4 & 4 & 4 & 4 & 4 & 0.6 \\
\hline$(6)$ & $\mathrm{NH}_{2} \bigcirc \mathrm{SO}_{2} \mathrm{~N}$ & $>8$ & 2 & 4 & 4 & 8 & 8 & 8 & 5 \\
\hline (7) & $\mathrm{NH}_{2} \circlearrowright \mathrm{SO}_{2} \mathrm{NH}$ & & 4 & 4 & 2 & 16 & 8 & 8 & 2.5 \\
\hline$(8)$ & $\mathrm{NH}_{2} \circlearrowright \mathrm{SO}_{2} \mathrm{NH}$ & $>2$ & 4 & 4 & 2 & 4 & 8 & 8 & $2: 5$ \\
\hline$(9)$ & $\mathrm{NH}_{2}<$ & $>2$ & 2 & 1 & 7 & 2 & 2 & 2 & 1.25 \\
\hline$(10)$ & $\mathrm{NH}_{2}<$ & 2 & 2 & 2 & 2 & 2 & 2 & 2 & 1.25 \\
\hline$(11)$ & $\mathrm{NH}_{2} \circlearrowright \mathrm{SO}_{2} \mathrm{~N}$ & $>4$ & 2 & 2 & 2 & 4 & 2 & 2 & 1.25 \\
\hline$(12)$ & $\int_{\mathrm{COOH}}^{\mathrm{CONH}} \longrightarrow \mathrm{SO}_{2} \mathrm{NH}^{N}{ }_{\mathrm{S}}$ & 2 & 1 & 1 & 2 & 1 & 1 & 1 & 3 \\
\hline (13) & $\bigcup_{\mathrm{COOH}}^{\mathrm{CONH}} \bigcirc \mathrm{SO}_{2} \mathrm{NH} \cdot \mathrm{CO} \cdot \mathrm{CH}_{3}$ & 2 & 2 & 2 & 2 & 1. & 1 & $i$ & 100 \\
\hline (14) & $\mathrm{NH}_{2} \bigcirc \mathrm{SO}_{2}-{ }_{\mathrm{S}}{ }_{\mathrm{NH}_{2}}^{\mathrm{N}}$ & $>2$ & $>4$ & $>8$ & 4 & 2 & 2 & 2 & 6.25 \\
\hline$(15)$ & $\mathrm{NH}_{2} \circlearrowright \stackrel{\mathrm{SO}_{2}}{\mathrm{CH}_{3}} \mathrm{~S}_{\mathrm{NH}_{2}}^{\mathrm{N}}$ & 2 & 2 & 2 & 2 & 2 & 2 & 2 & 12.5 \\
\hline (16) & $\mathrm{NH}_{2} \bigcirc \stackrel{\mathrm{SO}_{2}-\mathrm{C}_{S}-\mathrm{OH}}{\mathrm{N}}$ & $>4$ & 2 & 2 & 4 & 4 & 2 & 4 & 12.5 \\
\hline (17) & $\mathrm{NH}_{2} \circlearrowright \mathrm{SO}_{2}^{2}{ }_{\mathrm{S}}{ }_{\mathrm{SH}}^{\mathrm{N}}$ & & $>4$ & 4 & 2 & 2 & 2 & 2 & 25 \\
\hline (18) & $\mathrm{NH}_{i} \mathrm{CH}_{2} \bigcirc \mathrm{SO}_{2} \mathrm{NH}_{2} \cdot \mathrm{Hcl}$ & 1 & 1 & 1 & 1 & 1 & 1 & 1 & 500 \\
\hline$(19)$ & $\mathrm{NH}_{2}=\mathrm{C} \bigcirc \mathrm{SO}_{2} \mathrm{NH}_{2} \cdot \mathrm{Hcl}$ & 1 & 1 & 1 & 1 & 1 & 1 & 1 & $>1000$ \\
\hline$(20)$ & ${ }^{*} \mathrm{COOH} \longrightarrow \mathrm{SO}_{2} \mathrm{NH}_{2}$ & 1 & 1 & 1 & 1 & 1 & 1 & 7 & $>1000$ \\
\hline
\end{tabular}

一ル(ホモスルファミン) (19) スルフォンアミヂ ン(20) パラスルフォンアミドベンゼンカルボン ゾイレ。

\section{III 賽 驗 成 樍}

スルファチアゾールと尿絜とを併用した埸合の 成績は第1表に示す如くで，第 1 日ではスルフォ チアン゙ールの抗茵力は $10^{-5} \times 1 / 16$ であるが，尿 素を加えることによつて $10^{-5} \times 1 / 128$ 以上となつ $\tau 8$ 倍以上の力價の上泉が見られ，第 $3,5,7$ 日ではいずれも 4 倍の增强を示した。

同樣な方法で各檢體について試みた成績を一括
して示すと第2裴の通りとなる・表中の數字は尿 素を加えせ場合の檢體の抗菌力を，對照の尿素を 加えない检體だけの抗菌力で除しせ數である・ス ルフォンアミド乮の $\mathrm{N}^{1}$ 告異項環で遗撸された誘 導體のうち，チ广ン゙ール核を有するものは比較的 協同作用が强く，ピリミヂン核は弱いように思わ れた。またN゙がフターれ酸で置换されたものに、 一般に作用の減弱与るのか認められた。ズフォ オン誘導體についても協同作用が成立したが，大 ルフォンアミド劑の $\mathrm{N}^{4}$ の $\mathrm{NH}_{2}$ 基を $\mathrm{CH}_{2}$ 基, $\mathrm{COOH}$ 基, $\mathrm{C} \bigvee_{\mathrm{NH}_{2}}^{\mathrm{NH}}$ 基で置換された誘導體で 
は、このような現像は存在しなからた。

菌に對主る抗菌力はスルファチアジール，スル ファメチルチアゾールが最も優秀であつて，カル ボキシル基がつくと可なりの低下豪來し，スルフ アダイアヂン, スルファメラヂン,スルファメサ ヂンには抗菌力の差はなく，スルファチアブール についで高い力價を示した・スルフォンアミド劑 の $\mathrm{N}^{4}$ を脂肪族基, 芳香族基で置換された誘導體 恃，いちように原型に比して抗菌力の減弱方るの が認められたが，抗菌力と尿素との協同作用の强 さとの間には特別な關係は存在しなかつけこ。

\section{IV 考察とむすび}

スルフォンアミド劑の $\mathrm{N}^{1}$ を脂肪族基, 異項環 基で置換された誘導體， $\mathrm{N}^{4}$ の水素原子をフター ル酸で渞換された誘導體及びスルフォン誘導體に 物いては，强弱の程度の差はあるがずで尿素々 協同作用を認め得たが，スルフォンアミド劑の $\mathrm{N}^{4}$
の $\mathrm{NH}_{2}$ 基を他の原子團で监換された誘導體では， このような現象は存在しなかつたから，協同作用 の機作として $\mathrm{N}^{4}$ の $\mathrm{NH}_{2}$ 基が重要な役割を演じ ているものと思惟された。

またこれら尿素と協同作用を示さないスルフォ ンアミド劑はパラアミラ安息香酸によつて拮抗さ れず，尿素と協同する他のスルフォンアミド劑は すべてパラアミノ安息香酸によつて拮抗され，ス ルフォンアミド劑の作用に對する尿素とパラアミ ノ安息香酸とは逆の閵係になつていらから，その 効力の增强をめぐつて尿素とパラアミノ安息香酸 とが，深いつながりのあることが推測された。

終りに御指導と御校閱をいただいた 恩師入田貞義博 士に深謝致します：な括，越沼き及急顔の御援助にも御 禮申します。また本研究汢學術研究會議傳染性疾患䂰 究特別委員會の趼究援助によつてなされた・科會長小島 三郎博士に深く感謝致します。

\section{食品の新鮮保持に關する研究}

（2）牛乳を試驗基體とせる場合のニトロフ

ラゾーン゙ (邦製フラスキン) の防腐効果

日本醫科大學衞生學敉室（指導入田貞義敉授）

宮本睛夫·依田源治·中尾基久

柳町德三・越沼きみ㤩

\section{1. まえがき}

販賣用の牛乳に防腐劑を入れることは牛乳營業 取縍規則によつて嚴禁されているが，現今實施さ れている低溫殺菌 $\left(63^{\circ} \mathrm{C} 60\right.$ 分) の方法では, 規 則中に示されている如く，1c.c.中の細菌數を2 万個以下に保つことは甚だ困難のようであり, 且 つ乳酸菌を殺して胞子形成菌を繁殖させる憂もあ ろ. 分析用の牛乳サンプルには防霍劑として, 過
酸化水素, 次亞㘕素酸ソーダ, クロロフォルム, トルオール, キシロール, 重クローム酸カリ, 昇 永, フォルマリン等が涯加されるが, これ等は拎 用を全く無視して行われるもので，食品の新鮮保 持とはその意味を異にするものである。

わが呚室に於ては食品の新蘚保持に關方方研究 の一環として, 各種の化學療法劑及び飲食物の防 腐, 防徽劑等を用いて各種饮食物中の細菌に及ぼ 主影響を觀察中であるが，今日まで供試した薬荝 